J. Lake Sci. (湖泊科学), 2013, 25(5): 688-694

http: //www.jlakes.org. E-mail : jlakes@niglas. ac.cn

(c) 2013 by Journal of Lake Sciences

\title{
滆湖和骆马湖春季浮游植物光合作用活性的研究"
}

\author{
李大命 ${ }^{1}$, 阳 $\quad$ 振 $^{2}$, 于 洋 $^{2}$, 唐晟凯 ${ }^{1}$, 张粀晴 ${ }^{1}$, 周 刚 $^{1}$ \\ (1: 江苏省淡水水产研究所,南京 210017) \\ (2: 中国科学院南京地理与湖泊研究所湖泊与环境国家重点实验室,南京 210008)
}

\begin{abstract}
摘 要: 本研究应用 Phyto-PAM 菼光仪测定滆湖和骆马湖春季浮游植物的光合活性, 包括浮游植物最大光量子产量 $F_{\mathrm{V}} / F_{\mathrm{m}}$ (可变苂光与最大苂光之比)、有效光量子产量 $\Phi_{\mathrm{PSII}}$ (实际光合作用效率) 和快速光响应曲线 (RLC); 同时, 采用显微镜对 浮游植物进行镜检和计数. 结果表明: 滆湖蓝藻和硅藻的最大光量子产量分别为 $0.36 \sim 0.52$ 和 $0.27 \sim 0.53$, 实际光量子产 量分别为 $0.25 \sim 0.37$ 和 $0.25 \sim 0.36$, 没有检测到绿藻的光合活性, RLC 曲线表明蓝藻有较高的光合作用效率, 更易形成 优势种群; 骆马湖绿藻和硅藻的最大光量子产量分别为 $0.45 \sim 0.65$ 和 $0.41 \sim 0.49$, 实际光量子产量分别为 $0.25 \sim 0.32$ 和0. $19 \sim 0.25$, 没有检测到蓝藻的光合活性; 滆湖浮游植物丰度在 $530 \times 10^{4} \sim 4200 \times 10^{4} \mathrm{cells} / \mathrm{L}$ 之间, 平均值为 $2918 \times$ $10^{4} \mathrm{cells} / \mathrm{L}$, 群落组成以蓝藻门、硅藻门、隐藻门和裸藻门为主; 骆马湖浮游植物丰度在 $260 \times 10^{4} \sim 510 \times 10^{4}$ cells $/ \mathrm{L}$ 之间, 平 均值为 $379 \times 10^{4} \mathrm{cells} / \mathrm{L}$, 群落组成以硅藻门和绿藻门为主. 综合滆湖和骆马湖水体的营养水平、浮游植物丰度和光合作用活 性表明, 湖泊富营养化能提高浮游植物种群丰度和蓝藻的光合作用活性, 进而有利于蓝藻在浮游植物群落中占有竞争优势.

关键词: 湖泊富营养化; 光合活性; 浮游植物; 滆湖;骆马湖
\end{abstract}

\section{Photosynthetic activity of phytoplankton in Lake Gehu and Lake Luoma in spring}

LI Daming ${ }^{1}$, YANG Zhen ${ }^{2}$, YU Yang ${ }^{2}$, TANG Shengkai ${ }^{1}$, ZHANG Tongqing $^{1}$ \& ZHOU Gang ${ }^{1}$

(1: Freshwater Fisheries Research Institute of Jiangsu Province, Nanjing 210017, P. R. China)

(2: State Key Laboratory of Lake Science and Environment, Nanjing Institute of Geography and Limnology, Nanjing 210008, P. R. China)

Abstract:In the present study, Phyto-PAM was applied to measure maximal photochemical quantum yield of PSII $\left(F_{\mathrm{V}} / F_{\mathrm{m}}\right)$, actual photochemical efficiency of PSII $\left(\Phi_{\mathrm{PSII}}\right.$ ), and rapid light response curve (RLC) of phytoplankton samples collected from Lake Gehu and Lake Luoma in spring. Meanwhile, the cell numbers of phytoplankton were counted by microscopy. The results showed that values of $F_{\mathrm{V}} / F \mathrm{~m}$ and $\Phi_{\mathrm{PSII}}$ of cyanobacteria in Lake Gehu varied from 0.36 to 0.52 and from 0.27 to 0.53 , and Bacillariophyta, from 0.25 to 0.37 and from 0.25 to 0.36 , respectively, but there was no photochemical vitality of Chlorophyta. RLC has indicated that cyanobacteria has higher photochemical vitality and are prone to form advantage populations in Lake Gehu. On the other hand, the values of $F_{\mathrm{V}} / F \mathrm{~m}$ and $\Phi_{\mathrm{PSII}}$ of Chlorophyta and Bacillariophyta in Lake Luoma ranged from 0.45 to 0.65, from 0.41 to 0.49 , from 0.25 to 0.32 , and from 0.19 to 0.25 , respectively, and no photochemical vitality were found for cyanobacteria. The density of phytoplankton in Lake Gehu ranged from $530 \times 10^{4}$ to $4200 \times 10^{4}$ cells/ L, with an average of $2918 \times 10^{4}$ cells/L. Cyanophyta, Bacillariophyta, Cryptophyta and Euglenophyta were dominant in the phytoplankton community. The density of phytoplankton in Lake Luoma varied from $260 \times 10^{4}$ to $510 \times 10^{4}$ cells/L, with an average of $379 \times 10^{4}$ cells/L, Bacillaryophyta and Chlorophyta were dominant in the phytoplankton community. According to the comparison between nutritional level, the abundance and photochemical vitality of phytoplankton assemblages in the two lakes, the lake eutrophication can increase the abundance of phytoplankton and photosynthetic activity of cyanobacteria, and become in favor of gaining advantages in phytoplankton assemblages. Keywords: Lake eutrophication; photosynthetic activity; phytoplankton; Lake Gehu; Lake Luoma

* 江苏省青年自然科学基金项目 (BK2012488) 和江苏省五大湖泊资源环境监测项目 (江苏省海洋与渔业局, 2012) 联合资助. 2012-12-10 收稿; 2013-02-25 收修改稿. 李大命, 男, 1981 年生, 博士, 助理研究员; E-mail: ldm8212@126.com. 
浮游植物是水生生态系统的重要组成部分, 分布广泛, 种类繁多, 也是生态系统中的主要初级生产者. 浮游植物是水环境的重要指示生物, 广泛用于湖泊水体环境的评价, 可以指示湖泊的营养水 ${ }^{[1]}$. 反过来, 环境条件也能直接影响浮游植物的群落结构和种群丰度 ${ }^{[24]}$. 湖泊富营养化是当今世界面临的重大水环境 问题, 导致夏季蓝藻水华频繁发生,严重威胁水生态系统安全. 富营养水平是影响浮游植物竞争力及其优势 种属差异的重要因素,这种差异源于浮游植物生理特征对富营养化的响应不同 ${ }^{[5]}$. 因此,原位研究不同营养 水平湖泊浮游植物最基本的生理指标——光合活性, 对于深人认识浮游植物的演替规律和蓝藻水华的形成 过程有重要作用.

叶绿素荧光技术是评价植物光合活性的一种快速、无损伤的常用方法, 在过去几十年里取得了很大进 展. 叶绿素苂光参数众多, 能提供光合作用的多种信息. 德国 Walz 公司生产的 Phyto-PAM 浮游植物分析仪可 用于测定不同类群微藻 (如蓝藻、绿藻和硅藻) 的光合活性、生长、叶绿素含量、光能利用效率等, 并可用于确 定水体中不同类群微藻含量, 该仪器所需样品量少, 灵敏度高 ${ }^{[6]}$. 近年来, 该仪器被广泛用于水华蓝藻的光 合活性研究,如吴晓东等原位研究了太湖、巢湖和玄武湖越冬蓝藻的光和活性并比较了 3 个湖泊间的差 异 ${ }^{[7]}$, Verspagen 等测定了底泥中微囊藻最大光量子产量的动态变化 ${ }^{[8]}$, Goto 等调查了日本琵琶湖浮游植物 光合活性的时空变化,并分析了光合活性与环境因子间的关系 ${ }^{[9]}$.

本研究采用 Phyto-PAM 浮游植物苂光仪测定营养水平不同的两个湖泊——滆湖和骆马湖在春季浮游 植物的光合作用活性, 探讨湖泊富营养化对浮游植物光合作用活性和群落结构的影响, 同时为滆湖和骆马 湖的蓝藻水华监测和预警提供基础数据.

\section{1 材料和方法}

\section{1 采样点和水样采集}

滆湖 ( $\left.31^{\circ} 29^{\prime} \sim 31^{\circ} 42^{\prime} \mathrm{N}, 119^{\circ} 44^{\prime} \sim 119^{\circ} 53^{\prime} \mathrm{E}\right)$ 位于太湖流域西部, 是苏南地区仅次于太湖的第二大湖 泊, 属长江三角洲浅水湖泊类型. 湖面长茄形, 南北长 $25 \mathrm{~km}$, 东西平均宽约 $6.6 \mathrm{~km}$, 水域面积 $164 \mathrm{~km}^{2}$, 常年 平均水深 $1.27 \mathrm{~m}$, 总蓄水量 $2.15 \times 10^{8} \mathrm{~m}^{3}$. 具有饮用、灌溉、航运、游览和水产养殖等多种使用功能. 滆湖水质 污染严重, TN 和 TP 超标严重, 总体处于 V 类水质,超富营养化阶段 ${ }^{[10]}$. 根据滆湖营养水平和项目要求, 设 置 6 个采样点, 从北到南依次为 G1 至 G6(图 1).

骆马湖 $\left(34^{\circ} 00^{\prime} \sim 34^{\circ} 14^{\prime} \mathrm{N}, 118^{\circ} 06^{\prime} \sim 118^{\circ} 18^{\prime} \mathrm{E}\right)$ 位于江苏省北部, 是江苏省第四大淡水湖泊. 南北长 $27 \mathrm{~km}$, 最大宽 $20 \mathrm{~km}$, 平均宽 $9.63 \mathrm{~km}$. 最大水深 $5.5 \mathrm{~m}$, 平均水深 $3.3 \mathrm{~m}$, 水域面积 $260 \mathrm{~km}^{2}$, 是具有防洪、灌 溉、调水、水产、承运等综合利用功能的平原型水库 ${ }^{[11]}$. 1990s 以来, 由于区域经济的高速发展, 影响了湖水 水质, 生态环境受到破坏, 湖泊朝富营养化方向发展. 本研究在骆马湖设置 6 个采样点 ( L1 L6) (图 1).
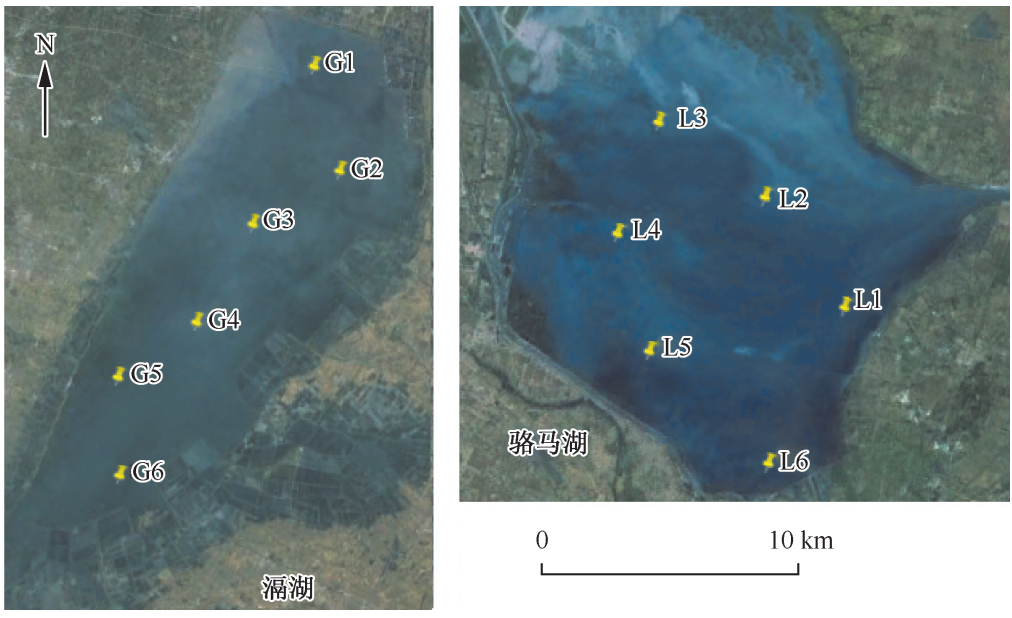

图 1 滆湖和骆马湖采样点

Fig. 1 Sampling sites in Lake Gehu and Lake Luoma 
水样采集在 2012 年 4 月中旬进行, 采用 GPS 对采样点准确定位, 使用有机玻璃采水器采集表层水样 $10.0 \mathrm{~L}$, 混合均匀, 取 $3.0 \mathrm{~L}$ 带回实验室进一步分析.

\section{2 理化因子测定}

采用多功能水质参数仪 YSI 6600 (Yellow Spring Instruments, USA) 原位测定采样点水体的理化参数, 包 括温度 (temperature, Tem)、溶解氧 (Dissolved oxygen, DO) 和 $\mathrm{pH}$ 值. 用赛氏盘测定水体的透明度 (SD), 钼酸 铵分光光度法测定总磷 ( TP), 碱性过硫酸钾消解一紫外分光光度法测定总氮 $(\mathrm{TN})$, 正磷酸盐 $\left(\mathrm{PO}_{4}^{3-}-\mathrm{P}\right)$ 、硝 态氮 $\left(\mathrm{NO}_{3}^{-}-\mathrm{N}\right)$ 和铵态氮 $\left(\mathrm{NH}_{4}^{+}-\mathrm{N}\right)$ 用 $0.45 \mu \mathrm{m}$ 滤膜抽滤后采用连续漂流分析仪 (Skalar San ${ }^{\text {plus }}$ analyzer, Netherlands) 测定. 叶绿素 a (Chl. a) 采用经过 GF/C 滤膜抽滤 $200 \sim 400 \mathrm{ml}$ 水样,充分研磨后, $90 \%$ 丙酮萃取的方 法进行测定 ${ }^{[12]}$.

\section{3 浮游植物镜检和计数}

取 $1 \mathrm{~L}$ 水样, 加人 $10 \mathrm{ml}$ 鲁哥试剂进行固定, 室温静置 $48 \mathrm{~h}$, 最后浓缩至 $30 \mathrm{ml}$. 浮游植物密度和种类组成 在显微镜下进行计数和鉴定. 计数方法采用目镜行格法, 一般随机计数两个垂直方格. 每个样品计数 2 次, 取平均值, 浮游植物丰度用 cells $/ \mathrm{L}$ 表示. 浮游植物种属的鉴定参照《淡水浮游生物研究方法》 ${ }^{[13]}$ 和《中国淡 水藻类——系统、分类及生态》 ${ }^{[14]}$.

\section{4 浮游植物光合活性测定}

应用浮游植物苂光仪 Phyto-PAM (Phyto-PAM, ED, Walz, Germany) 测定浮游植物光合活性. 取水样 $3 \mathrm{ml}$, 经过充分的暗适应 (15 min) 后, 首先打开光量子密度很弱的测量光 (Measuring radiation, ML), 仪器检 测到最小苂光 $F_{0}$, 接着打开饱和脉冲 ( saturation pulse), 得到最大苂光值 $F_{\mathrm{m}}$, 即可计算出最大光量子产量 $F_{\mathrm{V}} / F \mathrm{~m}$, 该值反映了浮游植物光合活性的最大潜能. 设定仪器每隔 $20 \mathrm{~s}$ 加以强度逐渐增大的光化光 (Actinic light), 同时记录光量子产量, 得到快速光响应曲线 (Rapid light curves, RLC). 再次打开饱和脉冲, 获得有效 量子产量 $\left(\Phi_{\mathrm{PSII}}\right)$, 该值反映光照状态下 PSII 的实际光合能力. 分析软件为 Phytowin 2.13 (Walz, Germany).

\section{5 数据的处理和分析}

数据采用 MS-Excel 2003 和 SPSS 16.0 软件进行分析, 应用 $t$-test 进行显著性水平检验, 采用 Origin 8.0 进行作图.

\section{2 结果和分析}

\section{1 滆湖和骆马湖水体理化因子}

两个湖泊采样点水体的理化因子存在差异 (表 1、图 2): 采样期间, 滆湖和骆马湖的水体温度分别 为 17.8 和 $16.2^{\circ} \mathrm{C}$, 差异不显著 $(P>0.05)$. 滆湖和骆马湖水体的总氮浓度分别为 4.66 和 $3.38 \mathrm{mg} / \mathrm{L}$, 总磷浓度分别为 0.201 和 $0.034 \mathrm{mg} / \mathrm{L}$, 滆湖的总氮、总磷浓度极显著高于骆马湖 $(P<0.01) .2$ 个湖泊 采样点的溶解性氮、磷浓度也具有相同趋势. 滆湖的 TN/TP 低于骆马湖. 滆湖和骆马湖水体的 $\mathrm{pH}$ 值相似, 滆湖水体的溶解氧浓度低于骆马湖, 差异不显著 $(P>0.05)$. 滆湖水体的透明度 $(23 \mathrm{~cm})$ 极显著低于骆马 湖 $(109 \mathrm{~cm})(P<0.01)$. 滆湖水体的叶绿素 a 浓度和营养状态指数 (Trophic state index, $T S I)^{[6]}$ 平均值分别 为 $39.59 \mu \mathrm{g} / \mathrm{L}$ 和 66.4 , 均极显著大于骆马湖的叶绿素 $\mathrm{a}$ 浓度 $(3.12 \mu \mathrm{g} / \mathrm{L})$ 和 $T S I(40.6)(P<0.01)$. 结合 2 个湖泊的氮、磷浓度及透明度可以得出, 采样期间, 滆湖水体属于富营养和超富营养化水平, 骆马湖属于中 营养化水平.

\section{2 滆湖和骆马湖浮游植物丰度}

滆湖浮游植物丰度在 $530 \times 10^{4} \sim 4200 \times 10^{4} \mathrm{cells} / \mathrm{L}$ 之间 (图 3), 平均值为 $2918 \times 10^{4} \mathrm{cells} / \mathrm{L}$, 群落组成以 蓝藻门、硅藻门、隐藻门和裸藻门为主, 优势种属有点状平裂藻 (Merismopedia punctata) 、微囊藻属 (Microcystis)、螺旋藻属 (Spirulina)、颗粒直链硅藻 (Melosira granulata)、卵形隐藻 (Cryptomonas ovata); 骆马湖浮 游植物丰度在 $260 \times 10^{4} \sim 510 \times 10^{4} \mathrm{cells} / \mathrm{L}$ 之间 (图 3), 平均值为 $379 \times 10^{4} \mathrm{cells} / \mathrm{L}$, 群落组成以硅藻门、绿 藻门和金藻门为主, 优势属有小环藻属 (Cyclotella)、桥弯藻属 (Cymbella)、四角藻属 (Tetraëdron)、栅藻属 (Scenedesmus)、锥囊藻属 (Dinobryon). 滆湖的浮游植物丰度极显著高于骆马湖 $(P<0.01)$, 优势种属也存在 差异. 
表 1 滆湖和骆马湖水体的理化因子

Tab. 1 Physico-chemical parameters of Lake Gehu and Lake Luoma

\begin{tabular}{|c|c|c|c|c|c|c|c|c|c|c|c|}
\hline 湖泊 & 采样点 & $\begin{array}{c}\mathrm{TN} / \\
(\mathrm{mg} / \mathrm{L})\end{array}$ & $\begin{array}{c}\mathrm{TP} / \\
(\mathrm{mg} / \mathrm{L})\end{array}$ & $\mathrm{TN} / \mathrm{TP}$ & $\begin{array}{c}\mathrm{PO}_{4}^{3-}-\mathrm{P} / \\
(\mu \mathrm{g} / \mathrm{L})\end{array}$ & $\begin{array}{c}\mathrm{NH}_{4}^{+}-\mathrm{N} / \\
(\mathrm{mg} / \mathrm{L})\end{array}$ & $\begin{array}{l}\mathrm{NO}_{3}^{-}-\mathrm{N} / \\
(\mathrm{mg} / \mathrm{L})\end{array}$ & $\begin{array}{c}\mathrm{Tem} / \\
{ }^{\circ} \mathrm{C}\end{array}$ & $\mathrm{pH}$ & $\begin{array}{c}\mathrm{DO} / \\
(\mathrm{mg} / \mathrm{L})\end{array}$ & $\begin{array}{l}\mathrm{SD} / \\
\mathrm{cm}\end{array}$ \\
\hline \multirow[t]{6}{*}{ 滆湖 } & G1 & 5.27 & 0.244 & 21.6 & 23.058 & 1.316 & 1.332 & 17.1 & 7.44 & 7.57 & 20 \\
\hline & G2 & 6.06 & 0.299 & 20.3 & 129.805 & 2.748 & 1.136 & 17.4 & 7.56 & 7.33 & 15 \\
\hline & G3 & 5.24 & 0.224 & 23.4 & 15.368 & 0.595 & 0.200 & 17.7 & 8.14 & 9.93 & 18 \\
\hline & G4 & 3.73 & 0.123 & 30.4 & 4.524 & 0.458 & 0.721 & 18.0 & 8.47 & 10.68 & 25 \\
\hline & G5 & 3.72 & 0.181 & 20.5 & 5.091 & 0.072 & 2.097 & 18.3 & 8.57 & 10.68 & 20 \\
\hline & G6 & 3.96 & 0.134 & 29.6 & 2.921 & 0.142 & 0.800 & 18.3 & 8.61 & 10.44 & 40 \\
\hline \multirow[t]{6}{*}{ 骆马湖 } & L1 & 3.37 & 0.030 & 110.4 & 2.512 & 0.007 & 1.158 & 17.2 & 8.49 & 12.08 & 180 \\
\hline & $\mathrm{L} 2$ & 3.91 & 0.032 & 121.1 & 2.096 & 0.007 & 0.312 & 15.9 & 8.21 & 11.47 & 75 \\
\hline & L3 & 2.94 & 0.048 & 61.7 & 4.375 & 0.039 & 0.768 & 16.8 & 8.19 & 10.38 & 50 \\
\hline & $\mathrm{L} 4$ & 3.66 & 0.029 & 125.3 & 2.985 & 0.004 & 1.568 & 15.8 & 8.14 & 12.08 & 80 \\
\hline & L5 & 2.91 & 0.033 & 89.0 & 3.379 & 0.016 & 0.892 & 16.1 & 7.98 & 11.42 & 110 \\
\hline & L6 & 3.48 & 0.029 & 118.6 & 2.131 & 0.029 & 0.891 & 15.5 & 7.52 & 10.99 & 160 \\
\hline
\end{tabular}
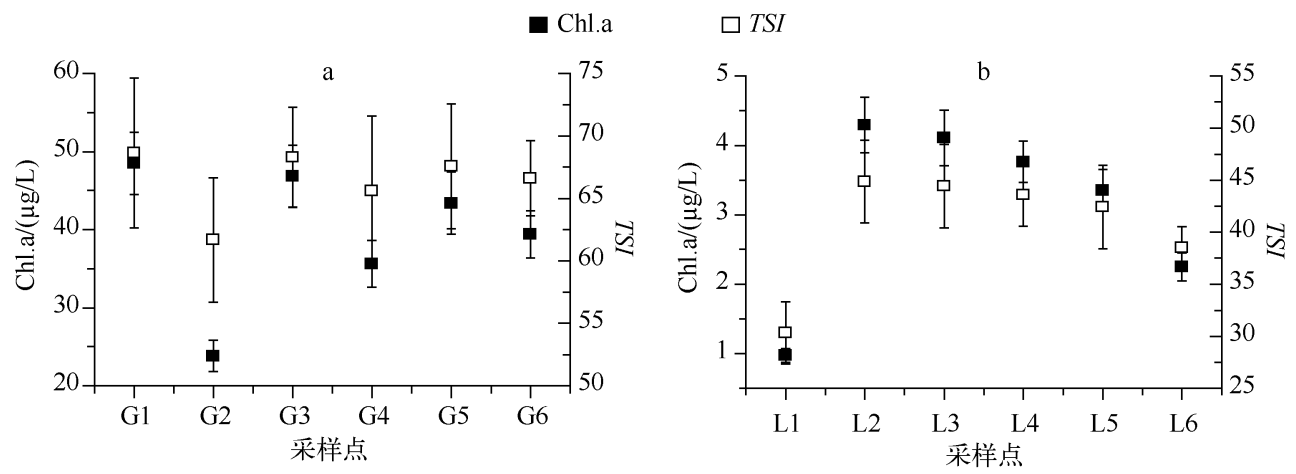

图 2 滆湖 (a) 和骆马湖 (b) 水体的叶绿素 a 浓度和营养状态指数

Fig. 2 Chl. a concentration and TSI of Lake Gehu (a) and Lake Luoma (b)
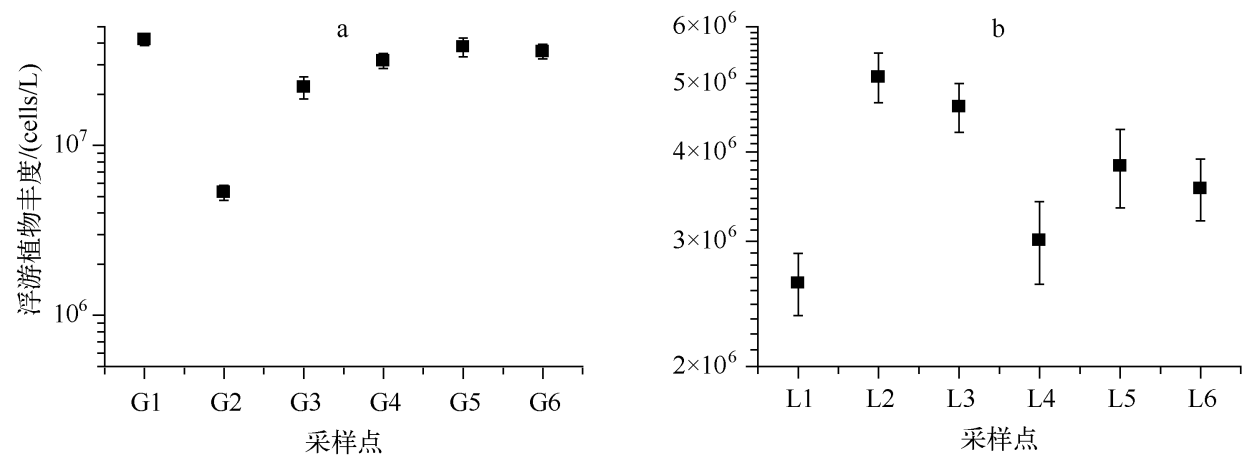

图 3 滆湖 (a) 和骆马湖 $(b)$ 浮游植物丰度

Fig. 3 Abundance of phytoplankton from Lake Gehu (a) and Lake Luoma (b)

\section{3 滆湖和骆马湖浮游植物的光合作用活性}

滆湖和骆马湖中浮游植物群落的光合作用活性具有显著差异: 在滆湖水样中, Phyto-PAM 菼光仪检测到 蓝藻和硅藻的光合作用活性, 其最大光量子产量分别在 $0.36 \sim 0.52$ 和 $0.27 \sim 0.53$ 之间,有效光量子产量分 
别在 $0.25 \sim 0.37$ 和 $0.25 \sim 0.36$ 之间, 没有检测到绿藻的光合作用活性; 在骆马湖水样中, 检测到绿藻和硅 藻的光合作用活性, 其最大光量子产量分别在 $0.45 \sim 0.65$ 和 $0.41 \sim 0.49$ 之间, 有效光量子产量分别在 $0.25 \sim 0.32$ 和 $0.19 \sim 0.25$ 之间, 没有检测到蓝藻的光合作用活性 (图 4).
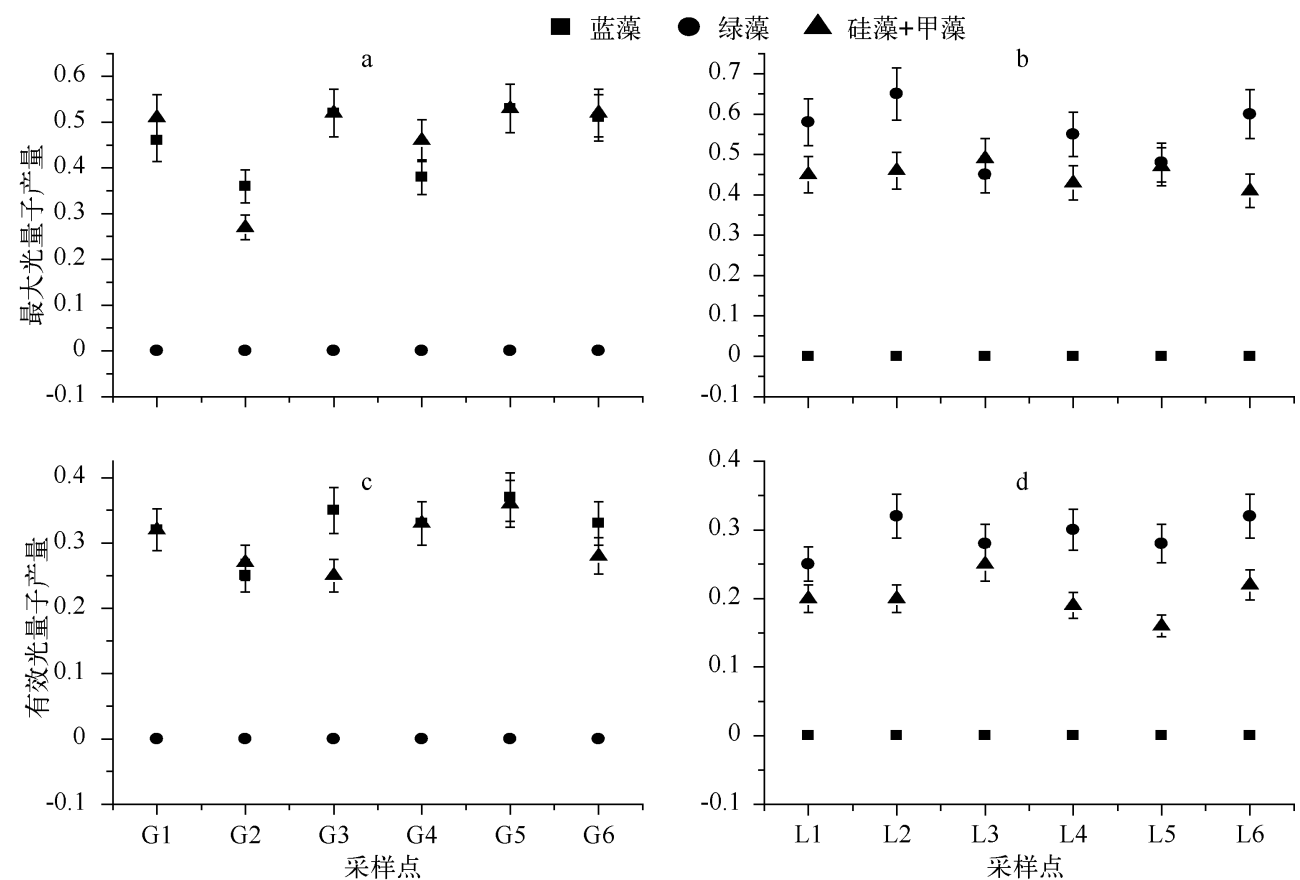

图 4 滆湖 $(a 、 c)$ 和骆马湖 $(b 、 d)$ 浮游植物群落的最大光量子产量和有效光量子产量

Fig. $4 F_{\mathrm{V}} / F \mathrm{~m}$ and $\Phi_{\mathrm{PSII}}$ of phytoplankton in Lake Gehu (a,c) and Lake Luoma(b,d)

快速光响应曲线 (RLC) 有 3 个特征参数: 线性区段斜率 $(\alpha)$ 、最大电子传递速率 (Maximum electron transport rate, ETRmax) 和饱和光照强度点 (Saturating light intensity, $I_{\mathrm{K}}$ ). 其中参数 $\alpha$ 与 ETRmax 表征浮游植 物的光合作用效率, $I_{\mathrm{K}}$ 表征浮游植物对光照强度的适应能力. 滆湖和骆马湖浮游植物群落的快速光响应曲线 的特征参数存在极显著差异: 滆湖水体中仅检出蓝藻和硅/甲藻的光合作用活性, 没有检出绿藻的光合作用 活性, 骆马湖则检出绿藻和硅/甲藻的光合作用活性, 没有检出蓝藻的光合作用活性. 从特征参数可以看出, 滆湖浮游植物群落中蓝藻有较高的光合作用效率, 骆马湖中绿藻有较高的光合作用效率, 滆湖中硅藻的光 合作用效率显著高于骆马湖 $(P<0.05)$, 且两个湖泊中浮游植物的快速光响应曲线的特征参数存在空间差 异(表2).

\section{3 讨论}

调制苂光仪 (Pulse Amplitude Modulated, PAM) 基于叶绿素苂光原理设计, 可以提供光合作用过程中 的诸多信息, 已成为研究植物光合作用的有效工具 ${ }^{[15]}$. 与传统的光合作用测定方法相比, PAM 检测法 具有快速、方便、灵敏度高等优势. 叶绿素菼光参数众多, 常用的有最大光量子产量、有效光量子产量 和光响应曲线 3 个特征参数 ${ }^{[16]}$. Phyto-PAM 浮游植物苂光分析仪能区分不同的浮游植物类群, 分别测 定其光合活性, 对浮游植物具有定性和定量分析功能, 已成为浮游植物生理生态学研究中最常用的 工具之一 ${ }^{[16]}$. 目前, 已应用 Phyto-PAM 荧光仪在室内开展了紫外辐射、营养盐、温度、光照、重金属 等对藻类光合活性的研究 ${ }^{[17-19]}$. 近年来 Phyto-PAM 在野外浮游植物光合活性研究中应用逐渐增多, 重点是测定水华蓝藻的光合作用活性. 蓝藻光合作用活性已经成为蓝藻水华监测和预警的重要基 础数据 ${ }^{[20-21]}$. 
表 2 光合活性参数——线性区段斜率、最大电子传递速率 $\left(\mu \mathrm{mol} /\left(\mathrm{m}^{2} \cdot \mathrm{s}\right)\right)$

和饱合光照强度点 $\left(\mu \mathrm{mol} /\left(\mathrm{m}^{2} \cdot \mathrm{s}\right)\right)$

Tab. 2 The photosynthetic parameters: efficiency $(\alpha)$, maximum electron transport rate $(E T R \max )$ and saturating light intensity $\left(I_{\mathrm{K}}\right)$

\begin{tabular}{|c|c|c|c|c|c|c|c|c|c|}
\hline \multirow{2}{*}{ 采样点 } & \multicolumn{3}{|c|}{ 蓝藻 } & \multicolumn{3}{|c|}{ 绿藻 } & \multicolumn{3}{|c|}{ 硅/甲藻 } \\
\hline & $\alpha$ & ETRmax & $I_{\mathrm{K}}$ & $\alpha$ & ETRmax & $I_{\mathrm{K}}$ & $\alpha$ & ETRmax & $I_{\mathrm{K}}$ \\
\hline G1 & $0.213 \pm 0.05$ & $143.5 \pm 10.8$ & $574.9 \pm 10.5$ & & & & $0.206 \pm 0.05$ & $224.4 \pm 7.8$ & $487.4 \pm 5.7$ \\
\hline G2 & $0.283 \pm 0.1$ & $168.1 \pm 6.2$ & $334.6 \pm 3.8$ & & & & $0.112 \pm 0.01$ & $178.3 \pm 6.5$ & $585.9 \pm 6.2$ \\
\hline G3 & $0.196 \pm 0.02$ & $115.5 \pm 5.5$ & $396.6 \pm 4.5$ & & & & $0.187 \pm 0.02$ & $81.2 \pm 3.2$ & $434.3 \pm 5.6$ \\
\hline G4 & $0.122 \pm 0.04$ & $47.1 \pm 2.8$ & $386.9 \pm 15.2$ & & & & $0.182 \pm 0.02$ & $182.7 \pm 5.5$ & $304.3 \pm 4.4$ \\
\hline G5 & $0.211 \pm 0.05$ & $275.9 \pm 3.6$ & $304.7 \pm 12.5$ & & & & $0.201 \pm 0.04$ & $226.3 \pm 8.5$ & $427.0 \pm 5.6$ \\
\hline G6 & $0.207 \pm 0.04$ & $158.0 \pm 6.7$ & $564.3 \pm 9.5$ & & & & $0.178 \pm 0.04$ & $83.6 \pm 4.8$ & $470.8 \pm 5.8$ \\
\hline L1 & & & & $0.166 \pm 0.02$ & $61.3 \pm 3.5$ & $369.1 \pm 10.2$ & $0.158 \pm 0.01$ & $85.6 \pm 5.5$ & $258.6 \pm 6.5$ \\
\hline L2 & & & & $0.168 \pm 0.04$ & $117.1 \pm 10.8$ & $746.9 \pm 20.8$ & $0.177 \pm 0.04$ & $53.4 \pm 2.8$ & $301.5 \pm 3.2$ \\
\hline $\mathrm{L} 3$ & & & & $0.172 \pm 0.05$ & $155.1 \pm 7.5$ & $918.8 \pm 15.4$ & $0.171 \pm 0.02$ & $119.7 \pm 6.5$ & $201.5 \pm 2.8$ \\
\hline L4 & & & & $0.168 \pm 0.02$ & $125.1 \pm 4.6$ & $746.9 \pm 18.5$ & $0.141 \pm 0.04$ & $49.2 \pm 5.2$ & $348.2 \pm 5.5$ \\
\hline L5 & & & & $0.169 \pm 0.05$ & $104.8 \pm 8.5$ & $608.3 \pm 12.6$ & $0.175 \pm 0.05$ & $91.5 \pm 4.4$ & $423.2 \pm 3.5$ \\
\hline L6 & & & & $0.170 \pm 0.1$ & $82.9 \pm 5.4$ & $525.4 \pm 8.7$ & $0.106 \pm 0.02$ & $96.1 \pm 3.8$ & $503.1 \pm 6.4$ \\
\hline
\end{tabular}

该研究首次采用 Phyto-PAM 浮游植物苂光仪原位测定滆湖和骆马湖春季浮游植物的光合作用活性. 结 果表明, 2 个湖泊中浮游植物群落的光合作用活性差异显著: 在处于富营养和超富营养化水平的滆湖浮游植 物群落中, 蓝藻有较高的光合作用活性, 在浮游植物群落中具有竞争优势, 绿藻受到抑制; 在处于中营养水 平的骆马湖浮游植物群落中, 绿藻和硅藻有较高光合作用活性, 蓝藻的光合作用活性受到抑制. 这与 2 个湖 泊的浮游植物群落组成具有一致性, 滆湖浮游植物群落组成以蓝藻门、硅藻门、隐藻门和裸藻门为主, 而骆 马湖浮游植物群落组成以硅藻门、绿藻和金藻门为主. 已有研究表明, 富营养化改变湖泊浮游植物的群落结 构, 有利于蓝藻在浮游植物群落中取得竞争优势 ${ }^{[22]}$. 结合本文研究结果可以得出, 浮游植物群落结构的变化 与浮游植物群落的光合作用活性有关, 湖泊富营养提高了蓝藻的光合作用活性, 有利于其取得竞争优势. 在 滆湖和骆马湖分别检出少量的绿藻和蓝藻细胞, 但 Phyto-PAM 并未检出其光合作用活性, 可能是由于藻密 度较低, 达不到 Phyto-PAM 的检测限 ${ }^{[7]}$, 也可能是因为它们的光合活性受到其它藻类群落抑制所致.

本研究中, 滆湖和骆马湖不同湖区的浮游植物光合作用活性存在差异. 比如, 滆湖蓝藻和硅藻最大光量 子产量分别在 $0.36 \sim 0.52$ 和 $0.27 \sim 0.53$ 之间, 骆马湖绿藻和硅藻最大光量子产量分别在 $0.46 \sim 0.65$ 和 $0.41 \sim 0.49$ 之间. 浮游植物的快速光响应曲线的特征参数在湖区间也存在差异, 这可能与不同种类浮游植 物的光合作用效率、采样点浮游植物的种类组成及环境因子差异有关. Goto 等调查了日本琵琶湖浮游植物 最大光量子产量的季节变化, 并分析与环境因子的关系, 揭示了浮游植物光合活性与与浮游植物生物量、种 类组成间的特定关系 ${ }^{[9]}$. Zhang 等研究了太湖浮游植物光合作用对光照和风浪扰动的响应, 探讨了蓝藻、绿 藻和硅/甲藻光合活性的日变化特征 ${ }^{[20]}$. 此外, 光照、温度、营养盐等均能影响浮游植物的光合作用活 性 ${ }^{[17-19]}$. 由此可见, 浮游植物的光合作用活性受浮游植物群落组成和环境因子的综合影响.

综上所述, 采样期间滆湖属于富营养化和超富营养化水平, 浮游植物群落组成以蓝藻、硅藻、隐藻和裸 藻为主,蓝藻密度和光合作用活性较高,生长潜能大, 随时间推移,夏季发生蓝藻水华的可能较大, 需要密切 监测; 骆马湖营养水平相对较低, 浮游植物群落以硅藻、绿藻、金藻为主, 硅藻和绿藻光合作用活性较高, 没 有检测到蓝藻的光合作用活性,发生蓝藻水华的概率较低.

\section{4 参考文献}

[ 1 ] Marchetto A, Padedda BM, Marinani M et al. A numerical index for evaluation phytoplankton response to changes in nutrient levels in deep mediterranean reservoirs. Journal of Limnology, 2009,68(1):106-121. 
[ 2 ] 邓建明,蔡永久,陈宇炜等. 洪湖浮游植物群落结构及其与环境因子的关系. 湖泊科学, 2010,22(1):70-78.

[3] 宋晓兰,刘正文,潘宏凯等.太湖梅梁湾与五里湖浮游植物群落的比较. 湖泊科学,2007,19(6):643-651.

[4] 李钦钦, 邓建才, 胡伟平等. 太湖金墅湾水源地浮游植物群落结构及其与环境因子的关系. 应用生态学报,2010,21 (7) : 1844-1850.

[ 5 ] Reynolds CS, Oliver RL, Walsby AE. Cyanobacterial dominance: the role of buoyancy regulation in dynamic lake environments. New Zealand Journal of Marine and Freshwater Research, 1987,21(3) : 379-390.

[6] 陈 元, 赵洋甬, 潘双叶等. Phyto-PAM 对浮游植物中叶绿素的分类测定. 现代科学仪器, 2009, (4) :100-103.

[ 7 ] 吴晓东, 孔繁翔, 曹焕生等. 越冬浮游植物光合作用活性的原位研究. 湖泊科学, 2007,19(2):139-145.

[ 8 ] Verspagen JMH, Snelder EOFM, Visser PM et al. Recruitment of benthic Microcystis (Cyanophyceae) to the water column: internal buoyancy changes or resuspension? Journal of Phycology, 2004,40(2):260-270.

[ 9 ] Goto N, Kihira M, Ishid N. Seasonal distribution of photosynthetically active phytoplankton using pulse amplitude modulated fluorometry in the large monomictic Lake Biwa, Japan. Journal of Plankton Research, 2008,30(10):1169-1177.

[10］张毅敏,张永春, 高月香等. 河湖相连水系水体污染控制技术与策略. 生态与农村环境学报, 2010, 26 (增刊 1 ): 9-13.

[11] 姜 波,赵秀兰. 骆马湖富营养化调查. 环境科学与技术,2003,26(增刊) :42-44.

[12］黄祥飞. 湖泊生态调查观测与分析. 北京:中国标准出版社,1999:77-79.

[13] 章宗涉,黄祥飞. 淡水浮游生物研究方法. 北京:科学出版社,1991:18-220.

[14] 胡鸿钧,魏印心. 中国淡水藻类一一系统、分类及生态. 北京: 科学出版社, 2006:23-900.

[15] Schreiber U, Neubauer C, Schliwa U. PAM fluorometer based on medium-frequency plused-Xe flash measuring light : a highly sensitive new tool in basic and applied photosynthesis research. Photosynthesis Research, 1993 ,36(1) :65-72.

[16] 张 曼, 曾 波. PhytoPAM 浮游植物分析仪用于微藻光合作用研究中几种参数设定的优化. 植物生理通讯, 2007, $\mathbf{4 3}(1)$ : $148-152$.

[17] Van der Grinten E, Janssen M, Simis SGH et al. Phospate regime structures species composition in cultured phototrophic biofilms. Freshwater Biology, 2004,49(4) :369-381.

[18] Gouvêa SP, Boyer GL, Twiss MR. Influence of ultraviolet radiation, copper, and zinc on microcystin content in Microcystis aeruginosa (Cyanobacteria). Harmful Algae, 2008,7(2):194-205.

[19] Deblois CP, Juneau P. Relationship between photosynthetic processes and microcystin in Microcystis aeruginosa grown under different photon irradiances. Harmful Algae, 2010,9 ( 1 ) : 18-24.

[20 ] Zhang M, Kong FX, Wu XD et al. Different photochemical responses of phytoplankters from the large shallow Taihu Lake of subtropical China in relation to light and mixing. Hydrobiologia, $2008, \mathbf{6 0 3}$ (1):267-278.

[21] 孔繁翔,马荣华,高俊峰等. 太湖蓝藻水华的预防、预测和预警的理论与实践. 湖泊科学,2009,21(3):314-328.

[22] Chen YW, Qin BQ, Teubner K et al. Long-term dynamics of phytoplankton assemblages:Microcystis-domination in Lake Taihu, a large shallow lake in China. Journal of Plankton Research, 2003,25 (1) : 445-453. 